NASA / TM-2005-213874

\title{
Boron Nitride Nanotubes-Reinforced Glass Composites
}

Narottam P. Bansal and Janet B. Hurst

Glenn Research Center, Cleveland, Ohio

Sung R. Choi

University of Toledo, Toledo, Ohio 
Since its founding, NASA has been dedicated to the advancement of aeronautics and space science. The NASA Scientific and Technical Information (STI) Program Office plays a key part in helping NASA maintain this important role.

The NASA STI Program Office is operated by Langley Research Center, the Lead Center for NASA's scientific and technical information. The NASA STI Program Office provides access to the NASA STI Database, the largest collection of aeronautical and space science STI in the world. The Program Office is also NASA's institutional mechanism for disseminating the results of its research and development activities. These results are published by NASA in the NASA STI Report Series, which includes the following report types:

- TECHNICAL PUBLICATION. Reports of completed research or a major significant phase of research that present the results of NASA programs and include extensive data or theoretical analysis. Includes compilations of significant scientific and technical data and information deemed to be of continuing reference value. NASA's counterpart of peerreviewed formal professional papers but has less stringent limitations on manuscript length and extent of graphic presentations.

- TECHNICAL MEMORANDUM. Scientific and technical findings that are preliminary or of specialized interest, e.g., quick release reports, working papers, and bibliographies that contain minimal annotation. Does not contain extensive analysis.

- CONTRACTOR REPORT. Scientific and technical findings by NASA-sponsored contractors and grantees.
- CONFERENCE PUBLICATION. Collected papers from scientific and technical conferences, symposia, seminars, or other meetings sponsored or cosponsored by NASA.

- SPECIAL PUBLICATION. Scientific, technical, or historical information from NASA programs, projects, and missions, often concerned with subjects having substantial public interest.

- TECHNICAL TRANSLATION. Englishlanguage translations of foreign scientific and technical material pertinent to NASA's mission.

Specialized services that complement the STI Program Office's diverse offerings include creating custom thesauri, building customized databases, organizing and publishing research results ... even providing videos.

For more information about the NASA STI Program Office, see the following:

- Access the NASA STI Program Home Page at http://www.sti.nasa.gov

- E-mail your question via the Internet to help@sti.nasa.gov

- Fax your question to the NASA Access Help Desk at 301-621-0134

- Telephone the NASA Access Help Desk at 301-621-0390

- Write to:

NASA Access Help Desk

NASA Center for AeroSpace Information 7121 Standard Drive

Hanover, MD 21076 
NASA/TM-2005-213874

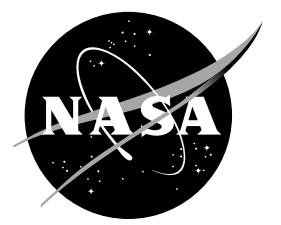

\section{Boron Nitride Nanotubes-Reinforced Glass Composites}

Narottam P. Bansal and Janet B. Hurst

Glenn Research Center, Cleveland, Ohio

Sung R. Choi

University of Toledo, Toledo, Ohio

Prepared for the

30th International Conference and Exposition on Advanced Ceramics and Composites sponsored by the American Ceramic Society

Cocoa Beach, Florida, January 22-27, 2006

National Aeronautics and

Space Administration

Glenn Research Center 


\section{Acknowledgments}

The authors are grateful to Dan Gorican for assistance during processing of BN nanotubes, Ralph Pawlik for mechanical testing, and John Setlock for composite fabrication. This work was supported by Low Emission Alternative Power (LEAP) and Alternate Energy Foundation Technology (AEFT) Programs,

NASA Glenn Research Center, Cleveland, Ohio.

Trade names or manufacturers' names are used in this report for identification only. This usage does not constitute an official endorsement, either expressed or implied, by the National Aeronautics and Space Administration.

This work was sponsored by the Low Emissions Alternative

Power Project of the Vehicle Systems Program at the NASA Glenn Research Center.

Available from

NASA Center for Aerospace Information 7121 Standard Drive

Hanover, MD 21076
National Technical Information Service 5285 Port Royal Road Springfield, VA 22100 


\title{
Boron Nitride Nanotubes-Reinforced Glass Composites
}

\author{
Narottam P. Bansal and Janet B. Hurst \\ National Aeronautics and Space Administration \\ Glenn Research Center \\ Cleveland, Ohio 44135 \\ Sung R. Choi \\ University of Toledo \\ Toledo, Ohio 43606
}

\begin{abstract}
Boron nitride nanotubes of significant lengths were synthesized by reaction of boron with nitrogen. Barium calcium aluminosilicate glass composites reinforced with $\sim 4$ weight percent of $B N$ nanotubes were fabricated by hot pressing. Ambient-temperature flexure strength and fracture toughness of the glass-BN nanotube composites were determined. The strength and fracture toughness of the composite were higher by as much as 90 and 35 percent, respectively, than those of the unreinforced glass.

Microscopic examination of the composite fracture surfaces showed pullout of the BN nanotubes. The preliminary results on the processing and improvement in mechanical properties of BN nanotube reinforced glass matrix composites are being reported here for the first time.
\end{abstract}

\section{Introduction}

Carbon nanotubes (CNT) show many properties which are superior to those of graphite. Boron nitride nanotubes (BNNT) have similar structure as CNT and exhibit many similar properties. Pure BNNTs were first synthesized using a plasma arc discharge method yielding mainly double walled BNNTs or by a CNT substitution reaction giving multiwalled BNNTs. Many other approaches, such as pyrolysis over cobalt, chemical vapor deposition, laser ablation and reactive milling, have been tried for the synthesis of BNNTs with varying degrees of success. BNNTs show interesting mechanical, electrical, and thermal properties. Pure CNTs show metallic or semiconducting behavior depending on composition, diameter, and chirality. On the other hand, BNNTs are semiconductors with a band gap of 4 to $5 \mathrm{eV}$. BNNTs are potential candidate materials for a large variety of nanosized electronic and photonic devices. CNTs oxidize in air at 400 to $600{ }^{\circ} \mathrm{C}$ and burn completely by $700{ }^{\circ} \mathrm{C}$, limiting their high temperature applications. On the other hand, BNNTs show stability (ref. 1) in air at $700{ }^{\circ} \mathrm{C}$. Some nanotubes with perfect cylindrical structure may be stable (ref. 1) up to $900^{\circ} \mathrm{C}$. BNNTs are, therefore, more suitable as reinforcement for composite materials for applications at elevated temperatures in oxidizing environment.

A number of studies are currently available on metal, ceramic and polymer matrix composites reinforced with CNTs as seen from the recent review articles (refs. 2 to 6). However, to the best of our knowledge, until now, no results have been published on the subject of BNNTs reinforced composites. The objective of this work was to improve the strength and fracture toughness of a solid oxide fuel cell (SOFC) seal glass (ref. 7) by reinforcing with BN nanotubes. Ambient-temperature mechanical properties including flexure strength and fracture toughness of glass-BN nanotube composite were determined. The results on the processing and mechanical properties of BNNTs reinforced glass matrix composites are being reported here for the first time. 


\section{Experimental Procedures}

Boron nitride nanotubes were synthesized in-house at NASA Glenn Research Center. Amorphous boron powder was mixed with several weight percent of fine iron catalyst particles in a hydrocarbon solvent and ball-milled in a polythene bottle using ceramic grinding media. The milled material was applied to various high temperature substrates such as alumina, silicon carbide, platinum and molybdenum and reacted in a flowing atmosphere of nitrogen containing small amount of ammonia. Nanotubes of significant length and abundance were formed on heat treatments at temperatures from 1100 to $1400{ }^{\circ} \mathrm{C}$ for $20 \mathrm{~min}$ to $2 \mathrm{~h}$. The resulting product consisted of a mixture of nanotubes and particulates of boron nitride. Batch sizes of typically $2 \mathrm{~g}$ were produced but the process should be easily scalable to larger amounts.

For composite processing, a barium calcium aluminosilicate (BCAS) (ref. 7) glass powder of composition (mol\%) $35 \mathrm{BaO}-15 \mathrm{CaO}-5 \mathrm{Al}_{2} \mathrm{O}_{3}-10 \mathrm{~B}_{2} \mathrm{O}_{3}-35 \mathrm{SiO}_{2}$ or $56.4 \mathrm{BaO}-8.8 \mathrm{CaO}-5.4 \mathrm{Al}_{2} \mathrm{O}_{3}-7.3 \mathrm{~B}_{2} \mathrm{O}_{3}-$ $22.1 \mathrm{SiO}_{2}(\mathrm{wt} \%)$ with an average particle size of $14.2 \mu \mathrm{m}$ was used. This glass composition labeled as G18 has a glass transition temperature of $619^{\circ} \mathrm{C}$, dilatometric softening point of $682{ }^{\circ} \mathrm{C}$, and coefficient of thermal expansion $10.5 \times 10^{-6} /{ }^{\circ} \mathrm{C}$ (from room temperature to $500{ }^{\circ} \mathrm{C}$ ) and $11.8 \times 10^{-6} /{ }^{\circ} \mathrm{C}\left(20\right.$ to $800{ }^{\circ} \mathrm{C}$ ). BCAS glass composites reinforced with $\sim 4 \mathrm{wt} \%$ of as-synthesized BNNTs were fabricated (ref. 8). Appropriate quantities of BCAS glass and BNNT were mixed in acetone, and ball milled for $\sim 24 \mathrm{~h}$ using zirconia milling media. Acetone was evaporated and the powder dried in an electric oven. The resulting mixed powder was loaded into a graphite die and hot pressed in vacuum at $630{ }^{\circ} \mathrm{C}$ under $10 \mathrm{MPa}$ for $15 \mathrm{~min}$ into 50 - by $25-\mathrm{mm}$ plates using a mini hot press. The applied pressure was released before onset of cooling. Glass powder without any BNNT was also hot pressed at $630{ }^{\circ} \mathrm{C}$. Grafoil was used as spacers between the specimen and the punches.

The hot-pressed plates were machined into flexure bar test specimens with nominal depth, width and length of 2.0 - by $3.0-$ by $25-\mathrm{mm}$, respectively. The final finishing was completed with a no. 500 diamond grinding wheel under the specified conditions in accordance with ASTM standard C1161 (ref. 9).

Machining direction was longitudinal along the $25 \mathrm{~mm}$-length direction. The sharp edges of test specimens were chamfered to reduce any spurious premature failure emanating from those sharp edges.

Strength testing was conducted in four-point flexure at ambient temperature in air. A test fixture with $10 \mathrm{~mm}$-inner and $20 \mathrm{~mm}$-outer spans was used in conjunction with an electromechanical test frame (Model 8562, Instron, Canton, MA). A stress rate of $50 \mathrm{MPa} / \mathrm{s}$ was applied in load control using the test frame. A total of 10 test specimens were tested. One of two $3 \mathrm{~mm}$-wide sides of each test specimen was subjected to maximum tension or compression. Although the specimen configuration was different, in general, testing was carried out in accordance with the ASTM test standards C 1161 (ref. 9).

Fracture toughness was determined using the flexure bar test specimens at ambient temperature in air using single edge v-notched beam (SEVNB) method (ref. 10). The same technique was previously used to measure fracture toughness of G18 glass and G18 glass composites reinforced with alumina or zirconia (ref. 8). This method utilizes a razor blade with diamond paste, grain size of $9 \mu \mathrm{m}$, to introduce a final sharp notch with a root radius ranging from 10 to $20 \mu \mathrm{m}$ by tapering a saw notch. The sharp v-notched specimens with a notch depth of about $1.0 \mathrm{~mm}$ along the $3 \mathrm{~mm}$-wide side of test specimens were fractured in a four-point flexure fixture with $10 \mathrm{~mm}$-inner and $20 \mathrm{~mm}$-outer spans using the Instron test frame (Model 8562) at an actuator speed of $0.5 \mathrm{~mm} / \mathrm{min}$. Three specimens were tested. Fracture toughness was calculated based on the formula by Srawley and Gross (ref. 11).

Morphology of the BN nanotubes, microstructures of polished cross-sections of hot pressed composites, and fracture surfaces of specimens after strength measurements were observed in a Hitachi S4700 field emission scanning electron microscope (FESEM) equipped with a super thin window EDAX Genesis System energy dispersive spectrometer (EDS). 


\section{Results and Discussion}

Field emission SEM micrographs of the BN nanotubes synthesized at NASA Glenn are shown in figure 1. BNNTs having diameter of 10 to $40 \mathrm{~nm}$ and of significant lengths (tens of microns) are observed. The nanotubes were found to consist of nearly stoichiometric BN. Spherical particles of boron nitride are also seen to be present in some areas.

Typical FE SEM micrographs showing polished cross-sections of the G18 glass reinforced with BN nanotubes are shown in figure 2 . The nanotubes are dispersed homogeneously in the matrix. From EDS analysis, it was found that the black regions consist of $\mathrm{BN}$ and the white particles were zirconia, most probably introduced as impurities during ball milling. Results of flexure strength testing for the G18 glass-BN nanotube composite are shown in figure 3. Strength of G18 glass (ref. 8) is also shown for comparison. The addition of just $4 \mathrm{wt} \%$ of $\mathrm{BN}$ nanotubes, increases the glass strength from $48 \pm 7 \mathrm{MPa}$ to $92 \pm 17 \mathrm{MPa}$. This 90 percent increase in strength of the glass with $\mathrm{BN}$ nanotube reinforcement is notable, compared with a moderate strength increase ( 40 to 60 percent) for G18 glass reinforced with $5 \mathrm{~mol} \%$ alumina platelets or zirconia particulates (ref. 8). Weibull strength distributions of the glass and $\mathrm{BN}$ nanotube-reinforced glass composite are presented in figure 4 despite insufficient number of test specimens used. Weibull modulus $(m)$ ranged from 7 to 8 , indicating the same degree of scatter in strength (or flaw population) for both the glass and the BN nanotube-glass composite. FESEM micrographs showing typical fracture surfaces of flexure-strength tested specimens of G18 glass reinforced with $4 \mathrm{wt} \% \mathrm{BN}$ nanotubes are shown in figure 5 . Limited amount of pullout of the nanotubes is observed as indicated by arrows. Troughs resulting from pullout of the nanotubes can also be seen in figure 5 .
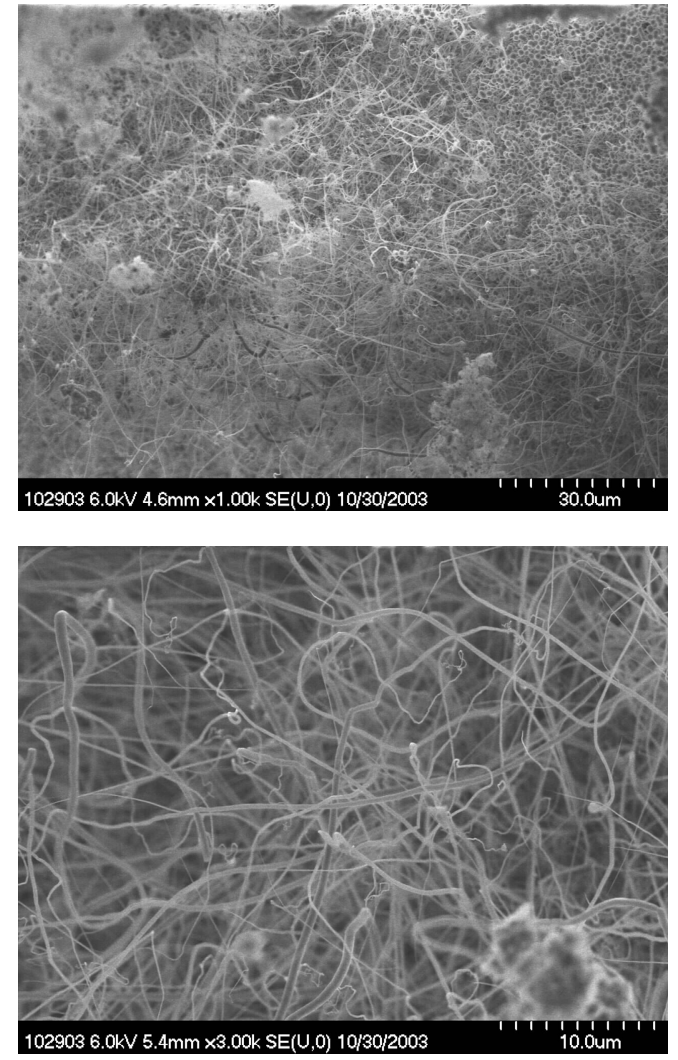
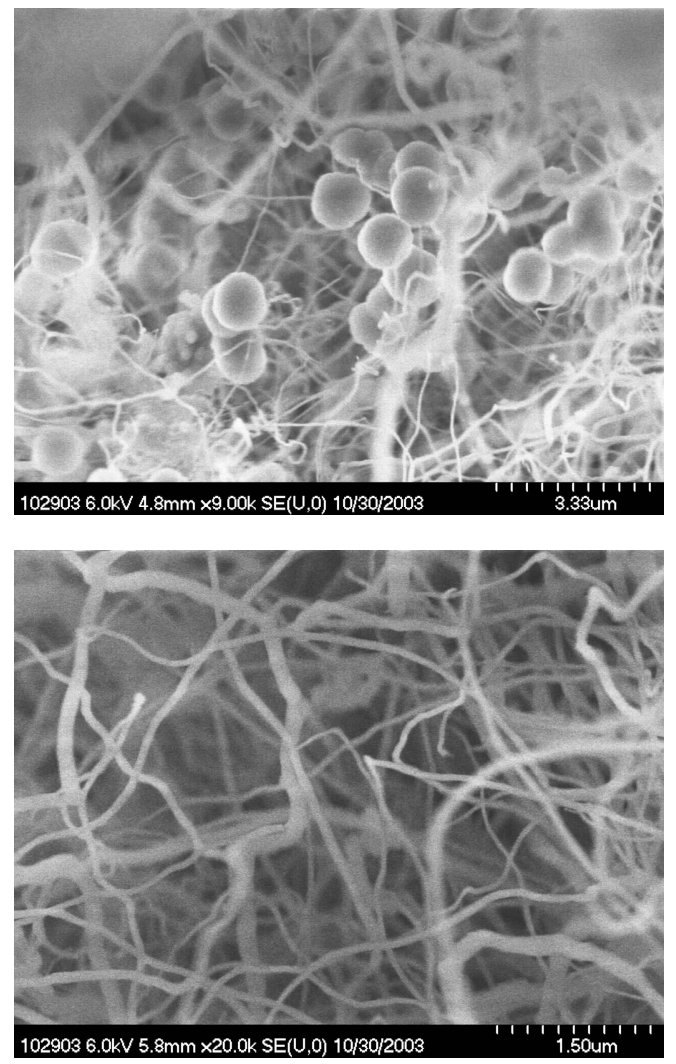

Figure 1.-Field emission SEM micrographs of BN nanotubes. 

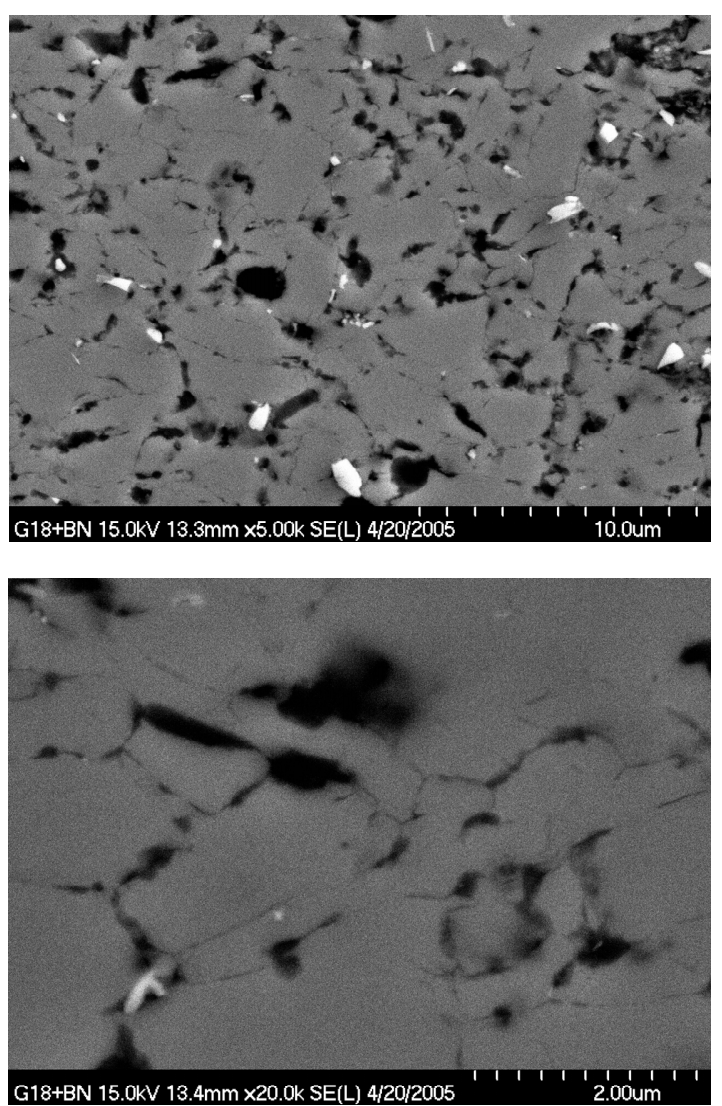

Figure 2.-Field emission SEM micrographs of polished cross-section of G18 glass composite reinforced with $4 \mathrm{wt} \% \mathrm{BN}$ nanotubes.

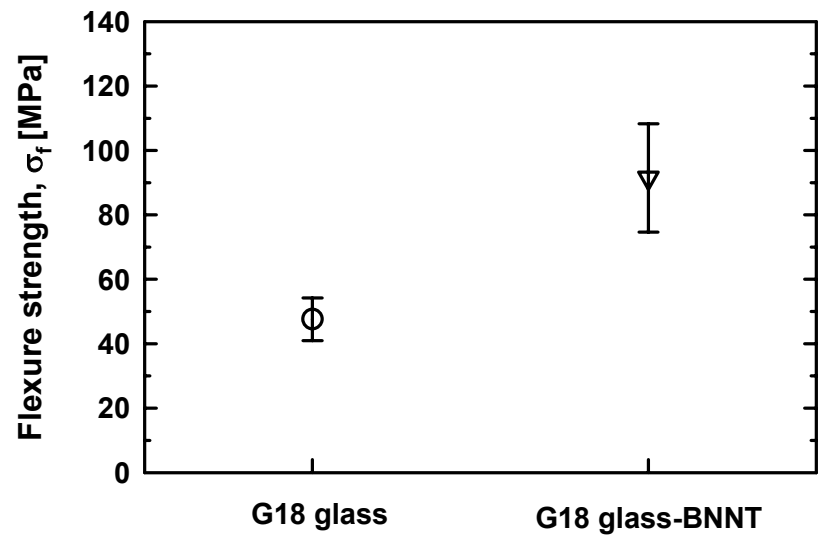

Figure 3.-Four-point flexure strength of G18 glass composite reinforced with $4 \mathrm{wt} \% \mathrm{BN}$ nanotubes.

Strength data for G18 glass are also included for comparison (ref. 8). Error bars indicate \pm 1.0 standard deviation.

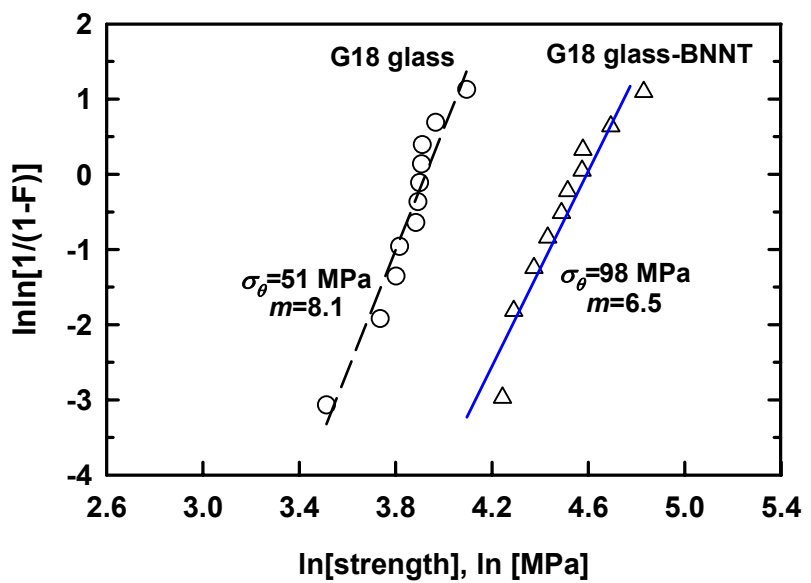

Figure 4.-Weibull strength distribution of G18 glass reinforced with $4 \mathrm{wt} \% \mathrm{BN}$ nanotubes. The Weibull data for G18 glass are also included for comparison (ref. 8); $m$ is the Weibull modulus and $\sigma_{\theta}$ is the characteristic strength. 

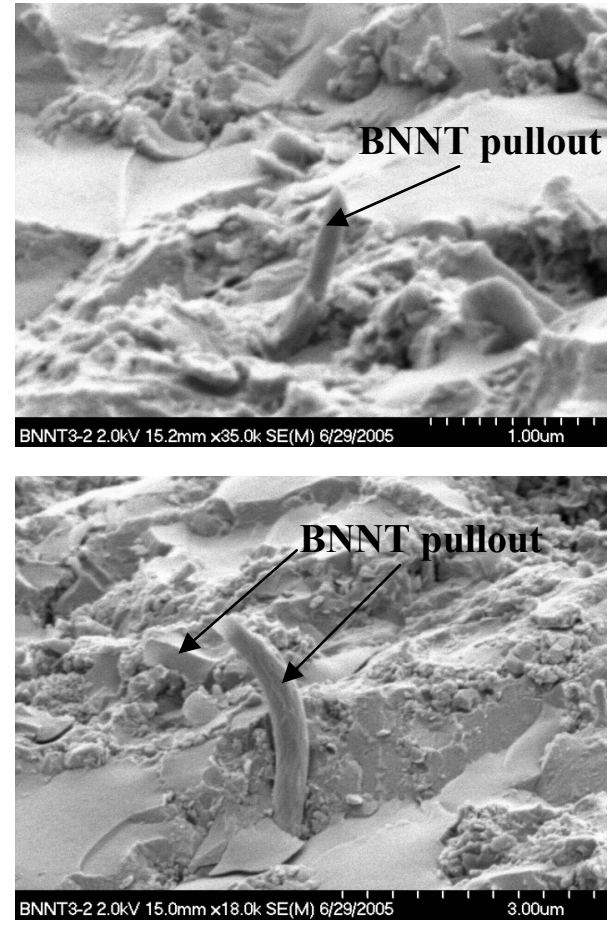
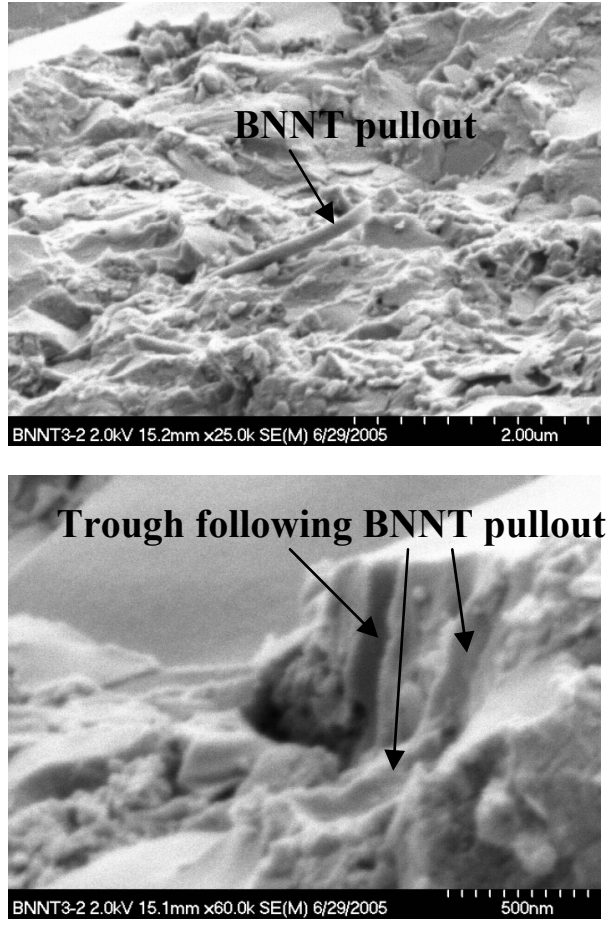

Figure 5.-FESEM micrographs showing typical fracture surfaces of flexure-strength tested specimens of $\mathrm{G} 18$ glass reinforced with $4 \mathrm{wt} \% \mathrm{BN}$ nanotubes.

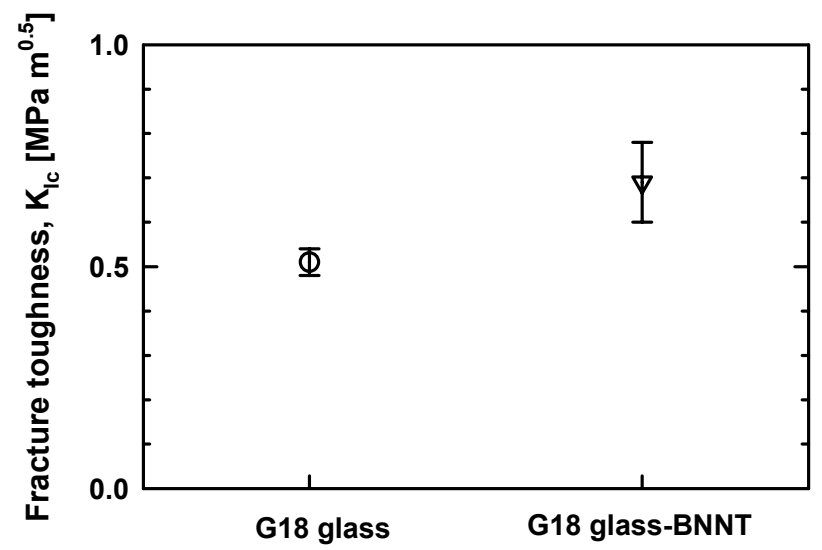

Figure 6.-Fracture toughness of G18 glass reinforced with $4 \mathrm{wt} \% \mathrm{BN}$ nanotube. Fracture toughness of G18 glass is also shown for comparison (ref. 8). Error bars indicate \pm 1.0 standard deviation.

The results of fracture toughness testing by the single edge v-notched beam (SEVNB) method are shown in figure 6. Fracture toughness shows a similar trend as strength. However, the increase in fracture toughness was less significant than strength. The addition of just $4 \mathrm{wt} \%$ of $\mathrm{BN}$ nanotubes, increases the fracture toughness $\left(K_{\mathrm{Ic}}\right)$ of glass from $0.51 \pm 0.03 \mathrm{MPa} \sqrt{\mathrm{m}}$ to $0.69 \pm 0.09 \mathrm{MPa} \sqrt{\mathrm{m}}$. This 35 percent increase in fracture toughness for the glass-BN nanotubes composite is comparable to that for the G18 glass composites reinforced with similar amounts of alumina or zirconia (ref. 8). 
Limited availability of the BN nanotubes reinforced glass composite did not allow the evaluation of $\mathrm{R}$-curve behavior or crack growth resistance of the composite material in the current study. However, it should be mentioned that the G18 glass reinforced with alumina platelets or zirconia particulates have exhibited a rising R-curve, with its degree being increased with increasing content of the reinforcement (ref. 8). Crack bridging and/or crack defection (ref. 12) was considered to be a major strengthening or toughening mechanism operative for those composites (ref. 8). A similar mechanism may also be attributed to a possible R-curve and the increase in strength and fracture toughness of the glass composite reinforced with $\mathrm{BN}$ nanotubes, as seen from figure 5 .

Due to their small size and large aspect ratio, CNTs are considered to be highly promising reinforcement materials as the energy dissipation during crack propagation can be greatly enhanced due to pull out. A few studies are available on the $\mathrm{SiC}$ (ref. 13), alumina (refs. 14 to 16), and glass matrix (ref. 17) composites reinforced with CNTs. Improvements in strength and fracture toughness of silica glass (ref. 17) and alumina (ref. 14) by the addition of 5 to 10 percent of CNTs have been reported earlier. However, Peigney et al. (refs. 15 to 16) failed to observe any beneficial effect on the mechanical properties of alumina from the addition of long carbon nanotube bundles.

The work presented in this paper has been done primarily for the purposes of the fabrication of glassBNNT composites and the determination of their ambient-temperature mechanical properties. However, SOFCs operate in a typical temperature range of 700 to $1000^{\circ} \mathrm{C}$, so that thermal and mechanical properties and environmental durability of the glass composites need to be evaluated at elevated temperatures, as done previously for 10-YSZ composites (ref. 18). Needed work includes constitutive relation, (viscosity)/sealability (ref. 19), coefficient of thermal expansion, intermediate-temperature strength, thermal fatigue, life limiting factors, and stability of material including crystallization (ref. 7), etc. Results of detailed investigations of this glass-BNNT composite system will be reported in the near future.

\section{Conclusions}

A barium calcium aluminosilicate (BCAS) glass composite containing $4 \mathrm{wt} \% \mathrm{BN}$ nanotubes was fabricated by hot pressing. Reinforcement with $\mathrm{BN}$ nanotubes improved both the flexure strength and fracture toughness of the glass. The strength of the composite was higher by as much as 90 percent and fracture toughness by as much as 35 percent than those of the glass. Microscopic examination of the fracture surfaces showed pull out of the nanotubes. The results on the processing and improved mechanical properties of $\mathrm{BN}$ nanotubes-reinforced glass matrix composites are being reported here for the first time.

\section{References}

1. Y. Chen, J. Zou, S.J. Campbell and G. Le Caer, Boron Nitride Nanotubes: Pronounced Resistance to Oxidation, Appl. Phys. Lett., 84[13], 2430-2432 (2004).

2. W.A. Curtin and B.W. Sheldon, CNT-Reinforced Ceramics and Metals, Materials Today, 7 [11] 44 49 (2004).

3. P.J.F. Harris, Carbon Nanotube Composites, Internatl. Mater. Rev., 49[1], 31-45 (2004).

4. H.D. Wagner and R.A. Vaia, Nanocomposites: issues at the Interface, Materials Today, 7 [11] 38-42 (2004).

5. E.T. Thostenson, Z. Ren, and T.W. Chou, Advances in the Science and Technology of Carbon Nanotubes and Their Composites: A Review, Comp. Sci. Technol., 61[13], 1899-1912 (2001).

6. E.T. Thostenson, C. Li, and T.W. Chou, Nanocomposites in Context: A Review, Comp. Sci. Technol., 65[3-4], 491-516 (2005).

7. N.P. Bansal and E.A. Gamble, "Crystallization Kinetics of a Solid Oxide Fuel Cell Seal Glass by Differential Thermal Analysis," J. Power Sources, in press (2005). 
8. S.R. Choi and N.P. Bansal, "Mechanical Properties of SOFC Seal Glass Composites," Ceram. Eng. Sci. Proc., 26 (2005).

9. ASTM C 1161, Test Method for Flexural Strength of Advanced Ceramics at Ambient Temperature," Annual Book of ASTM Standards, vol. 15.01, American Society for Testing \& Materials, West Conshohocken, PA (2004).

10. J. Kübler, (a) "Fracture Toughness of Ceramics Using the SEVNB Method: Preliminary Results," Ceram. Eng. Sci. Proc., 18[4] 155-162 (1997); (b) Fracture Toughness of Ceramics Using the SEVNB Method; Round Robin," VAMAS Report no. 37, EMPA, Swiss Federal Laboratories for Materials Testing \& Research, Dübendorf, Switzerland (1999).

11. J.E. Srawley and B. Gross, "Side-Cracked Plates Subjected to Combined Direct and Bending Forces," pp. 559-579 in Cracks and Fracture, ASTM STP 601, American Society for Testing and Materials, Philadelphia (1976).

12. K.T. Faber and A.G. Evans, "Crack Deflection Processes," Acta. Metall., 31[4] 565-576 (1983).

13. R.Z. Ma, J. Wu, B.Q. Wei, J. Liang, and D.H. Wu, Processing and Properties of Carbon NanotubesNano SiC Ceramic, J. Mater. Sci., 33, 5243-5246 (1998).

14. R.W. Siegel, S.K. Chang, B.J. Ash, J. Stone, P.M. Ajayan, R.W. Doremus, and L.S. Schadler, Mechanical Behavior of Polymer and Ceramic Matrix Nanocomposites, Scripta Met., 44, 2061-2064 (2001).

15. A. Peigney, Ch. Laurent, E. Flahaut, and A. Rousset, Carbon Nanotubes in Novel Ceramic Matrix Nanocomposites, Ceram. Int., 26, 677-683 (2000).

16. E. Flahaut, A. Peigney, Ch. Laurent, Ch. Marliere, F. Chastel, and A. Rousset, Carbon NanotubeMetal-Oxide Nanocomposites: Microstructure, Electrical Conductivities and Mechanical Properties, Acta Mater., 48, 3803-3812 (2000).

17. J. Ning, J. Zhang, Y. Pan, and J. Guo, Fabrication and Mechanical Properties of SiO2 Matrix Composites Reinforced by Carbon Nanotube, Mater. Sci. Eng., A357, 392-396 (2003).

18. S.R. Choi and N.P. Bansal, "Flexure Strength, Fracture Toughness, and Slow Crack Growth of YSZ/Alumina Composites at High Temperatures," J. Am. Ceram. Soc., 88[6] 1474-1480 (2005).

19. B.M. Steinetz, N.P. Bansal, F.W. Dynys, J, Lang, C.C. Daniels, J.L. Palko, and S.R. Choi, "Solid Oxide Fuel Cell Seal Development at NASA Glenn Research Center," presented at the 2004 Fuel Cell Seminar, San Antonio, TX, November 1-5, 2004; Paper no. 148 (2004). 


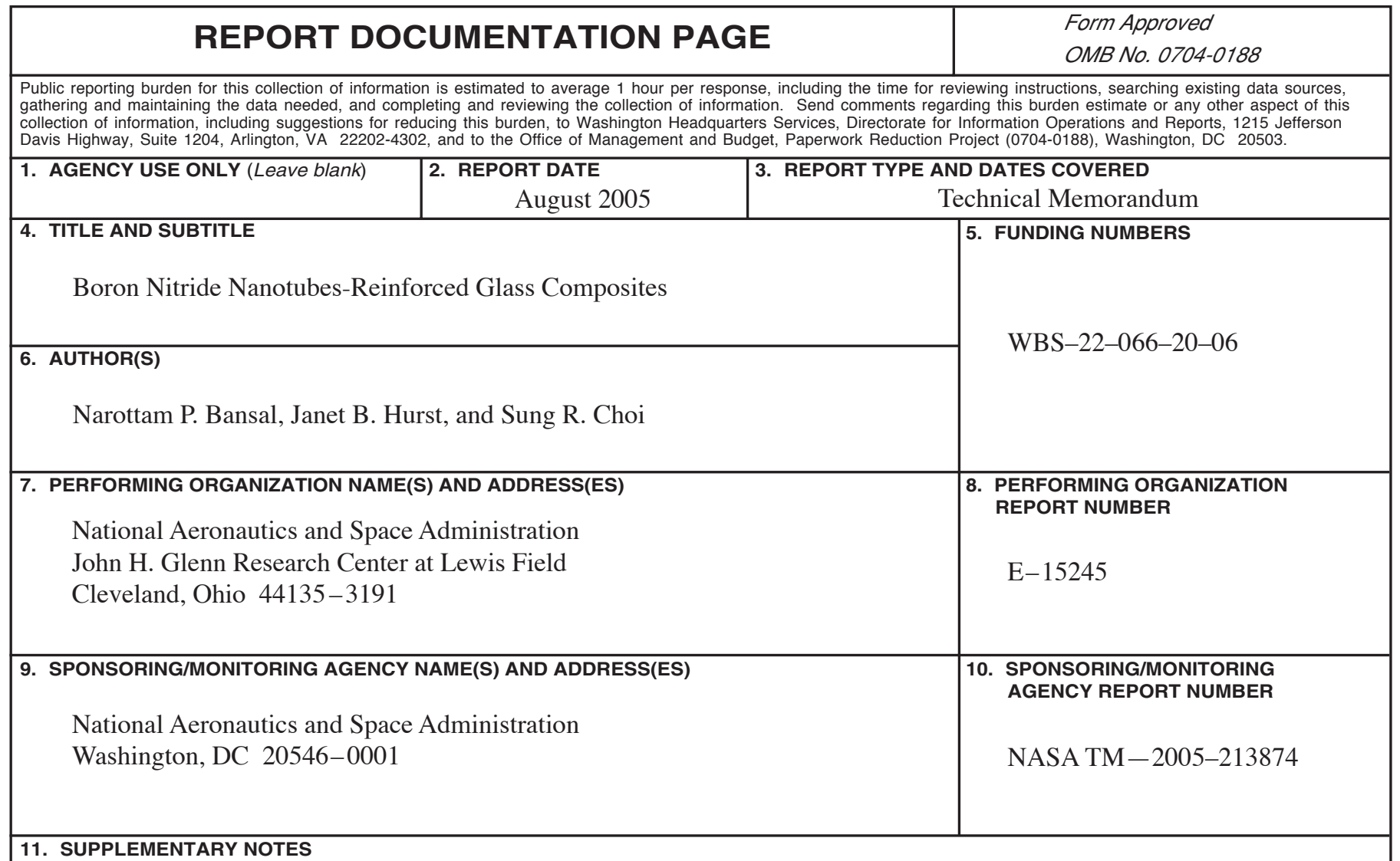

Prepared for the 30th International Conference and Exposition on Advanced Ceramics and Composites sponsored by the American Ceramic Society, Cocoa Beach, Florida, January 22-27, 2006. Narottam P. Bansal and Janet B. Hurst, NASA Glenn Research Center; and Sung R. Choi, University of Toledo, 2801 W. Bancroft Street, Toledo, Ohio 43606-3390. Responsible person, Narottam P. Bansal, organization code RMC, 216-433-3855.

12a. DISTRIBUTION/AVAILABILITY STATEMENT

12b. DISTRIBUTION CODE

Unclassified - Unlimited

Subject Categories: 24, 27, and 44

Available electronically at http://gltrs.grc.nasa.gov

This publication is available from the NASA Center for AeroSpace Information, 301-621-0390.

13. ABSTRACT (Maximum 200 words)

Boron nitride nanotubes of significant lengths were synthesized by reaction of boron with nitrogen. Barium calcium aluminosilicate glass composites reinforced with $\sim 4$ weight percent of BN nanotubes were fabricated by hot pressing. Ambient-temperature flexure strength and fracture toughness of the glass-BN nanotube composites were determined. The strength and fracture toughness of the composite were higher by as much as 90 and 35 percent, respectively, than those of the unreinforced glass. Microscopic examination of the composite fracture surfaces showed pullout of the BN nanotubes. The preliminary results on the processing and improvement in mechanical properties of BN nanotube reinforced glass matrix composites are being reported here for the first time.

\begin{tabular}{|c|c|c|c|}
\hline \multicolumn{3}{|l|}{ 14. SUBJECT TERMS } & $\begin{array}{c}\text { 15. NUMBER OF PAGES } \\
13\end{array}$ \\
\hline NSN 7540-0 & & & $\begin{array}{l}\text { ndard Form } 298 \text { (Rev. 2-89) } \\
\text { cribed by ANSI Std. Z39-18 } \\
102\end{array}$ \\
\hline
\end{tabular}



